\title{
Copaifera duckei oleoresin as a novel alternative for treatment of monogenean infections in pacu Piaractus mesopotamicus
}

\author{
Jaqueline Custódio da Costa ${ }^{a}$, Gustavo Moraes Ramos Valladão a , Gabriela Pala a , Sílvia Umeda Gallani ${ }^{\text {a }}$, \\ Suzana Kotzent ${ }^{\mathrm{b}}$, Antônio Eduardo Miller Crotti ${ }^{\mathrm{c}}$, Letícia Fracarolli ${ }^{\mathrm{c}}$, \\ Jonas Joaquim Mangabeira da Silva ${ }^{\mathrm{d}}$, Fabiana Pilarski ${ }^{\mathrm{a}, *}$

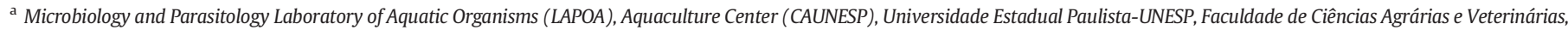 \\ Jaboticabal, São Paulo, Brazil

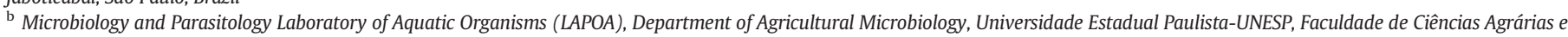 \\ Veterinárias, Jaboticabal, São Paulo, Brazil \\ c Chemistry Department, Universidade de São Paulo-USP, Faculdade de Filosofia, Ciências e Letras de Ribeirão Preto, Ribeirão Preto, São Paulo, Brazil \\ ' Department of Pharmaceutical Sciences, Universidade de São Paulo-USP, Faculdade de Ciências Farmacêuticas de Ribeirão Preto, Ribeirão Preto, São Paulo, Brazil
}

\section{A R T I C L E I N F O}

\section{Article history:}

Received 22 September 2016

Received in revised form 3 November 2016

Accepted 29 November 2016

Available online 6 December 2016

\section{Keywords:}

Aquaculture

Chemotherapeutics

Herbal medicine

Natural treatment

Parasite

Phytotherapy

\begin{abstract}
A B S T R A C T
Monogeneans are major parasites of fish and cause large economic losses in aquaculture. Treatment for this parasitic infection is done with products that are mostly toxic to fish and the environment. Essential oils (EOs) of Melaleuca alternifolia and Mentha piperita and the oleoresin (OR) of Copaifera duckei were tested for their in vitro anthelmintic activity against the monogenean parasites (Anacanthorus penilabiatus and Mymarothecium viatorum) of pacu Piaractus mesopotamicus. Naturally infected gills were bathed with the herbal solutions (100, $200,400,800$, and $1600 \mathrm{mg} / \mathrm{L}$ ) and monitored every $15 \mathrm{~min}$ for $4 \mathrm{~h}$. Because of its greater efficacy in vitro $(p<0.05)$ compared to the other herbal medicines, $C$. duckei OR was selected for in vivo testing. The in vivo treatment consisted of 10 and $50 \mathrm{mg} / \mathrm{L}$ baths of $C$. duckei OR for $10 \mathrm{~min}$. Parasitological, hematological, and histological analyses were conducted post-bath and seven days after treatment. Parasite loads decreased by approximately $45 \%$ in fish treated with $50 \mathrm{mg} / \mathrm{L}$ of $C$. duckei OR. No hematological changes caused by treatment with $C$. duckei OR at 10 and $50 \mathrm{mg} / \mathrm{L}$ were observed. Histology revealed branchial and hepatic alterations in fish from all groups, whereas spleen and kidney tissues were not affected. Histopathological alterations observed in all fish were due to parasitism or nutritional/farming conditions. Hematological and histological results showed that short baths were safe for fish. Based on the strong anthelmintic activity observed, C. duckei OR offers a promising alternative treatment against monogenean parasites.
\end{abstract}

(C) 2016 Elsevier B.V. All rights reserved.

\section{Introduction}

Monogenea are small parasitic flatworms (Platyhelminthes) of fish that in high numbers cause several epithelial and hematological alterations (Tavares-Dias et al., 2008; Araújo et al., 2009), predisposing the host to secondary infections and often leading to significant mortality (Huang et al., 2013; Ogawa, 2014). The use of therapeutic agents is necessary to minimize the economic losses caused by parasitic outbreaks in aquaculture (Valladão et al., 2015). The chemotherapeutic agents most used against monogeneans are hydrogen peroxide (Bowker et al., 2012; Benavides-González et al., 2015; Hirazawa et al., 2016), potassium permanganate (Umeda et al., 2006), formalin (Fajer-Ávila et al., 2003;

\footnotetext{
* Corresponding author at: Rod. Paulo Donato Castellane, s/n, CEP: 14.884-900 Jaboticabal, SP, Brazil.

E-mail address: fabianap@caunesp.unesp.br (F. Pilarski).
}

Pahor-Filho et al., 2012), and praziquantel (Sharp et al., 2004; Sitjà-Bobadilla et al., 2006; Forwood et al., 2013). However, due to their negative effects on the environment (Rico and Van den Brink, 2014) and in animals and humans (Sapkota et al., 2008), the use of some of these molecules is discouraged. Phytotherapy is an alternative treatment that has shown promising antiparasitic effects, especially against monogeneans (Reverter et al., 2014; Valladão et al., 2015). Currently, there is no alternative treatments for the control of monogeneans infections in pacu Piaractus mesopotamicus (Holmberg, 1887) and Copaifera duckei OR had not yet been tested in fish for any given purpose.

Phytotherapeutic agents extracted from Melaleuca alternifolia, Mentha piperita, and Copaifera L. have been used for different therapeutic applications. Melaleuca alternifolia is an Australian native plant with broad antiseptic, antimicrobial, anti-inflammatory, and antiparasitic activity (Thomsen et al., 2011). Recent studies have shown that the 
essential oil (EO) of M. alternifolia has been successfully used against the platyhelminths Gyrodactylus spp. (Steverding et al., 2005) and the protozoan Ichthyophthirius multifiliis (Valladão et al., 2016a).

Mentha piperita has a broad spectrum antiseptic, antifungal, antispasmodic, and immunostimulant activity (McKay and Blumberg, 2006). Recently, the EO of this plant has shown promising potential against several platyhelminths such as Dawestrema spp. in Arapaima gigas (Schinz, 1822) (Malheiros et al., 2016), Cichlidogyrus tilapiae, Cichlidogyrus thurstonae, Cichlidogyrus halli, and Scutogyrus longicornis in Oreochromis niloticus (Linnaeus, 1758) (Hashimoto et al., 2016), and against the protozoan I. multifiliis in pacu P. mesopotamicus (Valladão et al., 2016a).

Trees in the genus Copaifera are Amazon plants known for their antibacterial (Bardají et al., 2016), anthelmintic (Gilbert et al., 1972), antiprotozoal (Santos et al., 2008; Dorneles et al., 2013; Izumi et al., 2013), and antioxidant (Paiva et al., 2004) properties. Plants in this genus are usually rich in oleoresin (OR), which is extracted directly from the tree trunk (Veiga and Pinto, 2002), but little is known about the use of OR in aquaculture. Some studies have described the effects of Copaifera duckei OR against major parasitic protozoans of mammals such as Leishmania amazonensis (Santos et al., 2008), Trypanosoma cruzi (Izumi et al., 2013), and Trypanosoma evansi (Dorneles et al., 2013).

Pacu P. mesopotamicus is a South American fish of great economic importance because it is one of the main fish species cultured in continental waters (Valladão et al., 2016b). Similar to several fish species cultivated worldwide, pacu is highly affected by monogenean infections and thus constitutes a good biological model for studying the in vitro and in vivo effect of herbal medicines on monogenean parasites.

This study evaluated the in vitro activity of M. alternifolia, M. piperita, and $C$. duckei against two monogenean species and the in vivo effect of $C$. duckei oleoresin on the parasites and on host health.

\section{Materials and methods}

\subsection{Essential oils and chromatographic profile}

The EOs of $M$. alternifolia and $M$. piperita were purchased from Phytoterapica ${ }^{\circledR}$ (São Paulo, SP, Brazil). The oleoresin of $C$. duckei was collected in a sustainable manner from a tree trunk in Pará, northern Brazil $\left(1.9981^{\circ} \mathrm{S}, 54.9306^{\circ} \mathrm{W}\right)$. Extraction of plant material was authorized by the Chico Mendes Institute for Biodiversity Conservation (ICMBio) and the Brazilian Ministry of Environment (MMA), under number 35143-1. Two herbarium specimens were deposited in the ICMBio herbarium under code NID 03/2013.

The chemical characterization of the EOs was done using gas chromatography-mass spectrometry (GC-MS) as previously described in Baldin et al. (2013). The oleoresin was initially analyzed by high-performance liquid chromatography-mass spectrometry (HPLC-MS). Next, hydrodistillation was performed to obtain a volatile fraction using GCMS as described by Santiago et al. (2015) and Bardají et al. (2016).

The stock solutions of each phytotherapeutic agent were prepared with $0.1 \mathrm{~g}$ of the plant extract solubilized in $2 \mathrm{~mL}$ of dimethyl sulfoxide (DMSO; Sigma-Aldrich ${ }^{\circledR}$, St. Louis, MI, USA).

\subsection{Host and parasites}

Naturally infected pacu juveniles (weight: $75.25 \pm 14.47 \mathrm{~g}$ and length: $16.29 \pm 1.15 \mathrm{~cm}$; mean $\pm \mathrm{SD}$ ) were obtained from a commercial fish farm. Fish were kept in 500-L tanks with constant aeration and continuous water flow. Water quality parameters were measured using an YSI Professional Plus ${ }^{\circledR}$ multiparameter probe (YSI Inc., Yellow Springs, $\mathrm{OH}, \mathrm{USA}$ ). Water quality parameters were not significantly different across treatments: water temperature $\left(31.02 \pm 0.15^{\circ} \mathrm{C}\right)$, dissolved oxygen $(6.26 \pm 0.13 \mathrm{mg} / \mathrm{L}), \mathrm{pH}(8.1 \pm 0.05)$, and conductivity $(157.32 \pm 0.29 \mu \mathrm{S} / \mathrm{cm})$.
Monogenean parasites were scrapped from the gills and counted under a stereomicroscope. The parasites were collected and preserved in $70 \%$ alcohol for identification using fish parasite identification keys (Thatcher, 2006). The monogenean species were identified as Anacanthorus penilabiatus (Boeger et al., 1995) and Mymarothecium viatorum (Boeger et al., 2002).

The experimental procedures were approved by the Ethics and Animal Welfare Committee (CEUA) of the School of Agricultural Sciences and Veterinary Medicine at São Paulo State University (UNESP), Jaboticabal, SP, Brazil, under protocol number 12291/15.

\subsection{In vitro assay}

The in vitro study was conducted to evaluate and compare the anthelmintic activity of the EOs of M. alternifolia and M. piperita and the OR of $C$. duckei on monogenean parasites.

Gill samples were placed in Petri dishes and filled with $20 \mathrm{~mL}$ of water from the fish tank. Five concentrations of each herbal stock solution $(100,200,400,800$, and $1600 \mathrm{mg} / \mathrm{L})$ were tested. Two control groups were tested: DMSO (solubilization solution) and water only. Parasites were observed every $15 \mathrm{~min}$ for $4 \mathrm{~h}$. Mortality was recorded by verification of absence of movement when parasites were stimulated with a needle.

\subsection{In vivo assay}

Based on the results of the in vitro study, the OR of $C$. duckei was chosen for the in vivo test. Ninety-six naturally infected pacu juveniles were assigned to four treatments: fish not exposed to any substance (control), fish exposed to DMSO solution, and fish exposed to 10 and $50 \mathrm{mg} / \mathrm{L}$ of $C$. duckei OR. These concentrations were chosen from preliminary tests that showed no change in the fish behavior.

The experiment consisted of one short 10-min bath in plastic buckets containing $10 \mathrm{~L}$ of water. Fish were bathed two at a time and, at the end of each bath, one fish was collected for parasitological, histological, and hematological analyses, whereas the other fish returned to the tank $(500 \mathrm{~L})$ where it remained for seven days. Each treatment consisted of 12 replicates. Fish were anesthetized with benzocaine $(0.1 \mathrm{~g} / \mathrm{L})$ and euthanized for tissue sampling.

\subsubsection{Parasitological analysis}

All branchial arches on one side of each fish were harvested and placed into Petri dishes for parasites counting under a stereomicroscope, whereas branchial arches on the other side were collected for histology. The result was doubled to estimate the total amount of parasite per fish. The prevalence and mean intensity of parasites was calculated according to Bush et al. (1997).

\subsubsection{Effect of $C$. duckei OR on the host}

After anesthesia, fish blood was taken at days 0 and 7 after treatment. Blood count (red blood cells (RBC), hematocrit, and hemoglobin) was performed using the entire blood sample diluted in $10 \mu \mathrm{L}$ of heparin $5000 \mathrm{IU} / \mathrm{mL}$. For RBC (\%), $10 \mu \mathrm{L}$ of blood was diluted in $2 \mathrm{~mL}$ of formalincitrate solution for subsequent counting using a Neubauer chamber (Hesser, 1960). Hemoglobin ( $\mathrm{g} \mathrm{dL}^{-1}$ ) was measured using a hemoglobin assay kit (Labtest ${ }^{\circledR}$ kit \#43; Labtest, Lagoa Santa, MG, Brazil). Hematocrit percentage and RBC parameters mean corpuscular volume ( $\mathrm{MCV}$, in $\mathrm{fL}$ ), mean corpuscular hemoglobin ( $\mathrm{MCH}, \mathrm{pg}$ ), and mean corpuscular hemoglobin concentration (MCHC, \%) were measured according to Ranzani-Paiva et al. (2013). Blood smears were stained with MayGrünwald Giemsa-Wright (MGGW) and used for total counts and differential leukocyte counts according to Ranzani-Paiva et al. (2013).

The serum was obtained by centrifugation $(3000 \mathrm{rpm} \times 10 \mathrm{~min}$ at $4{ }^{\circ} \mathrm{C}$ ) and stored $\left(-20^{\circ} \mathrm{C}\right)$ until use. Total protein and albumin concentrations ( $\mathrm{g} \mathrm{dL}^{-1}$ ) were determined by spectrophotometry with $20 \mu \mathrm{L}$ and $10 \mu \mathrm{L}$ of serum using Labtest ${ }^{\circledR}$ kits \#99 and \#19, respectively. 


\section{Melaleuca alternifolia}

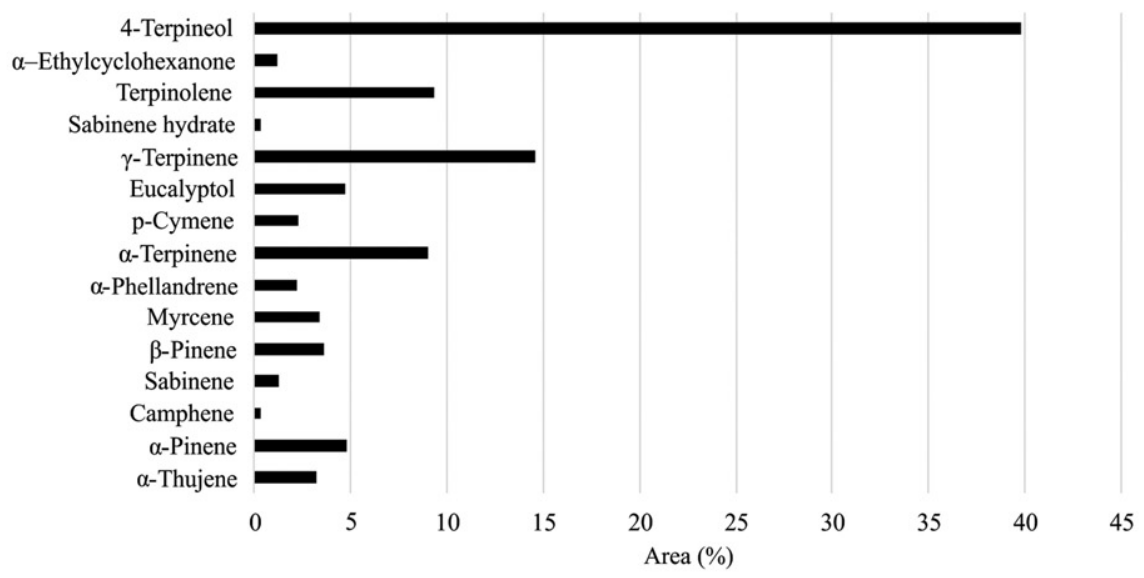

\section{Mentha piperita} Bicyclo[5.2.0]nonane, 2-methylene-4,8,8-trimethyl-4-vinyl ।

Alloaromadendrene Germacrene D

Humulene $=$

1,7-di-epi- $\beta$-cedreno

Caryophyllene

$\beta$-elemene ,

$(-)-\beta$-Bourbonene "

trans,trans, trans-Bicyclo[4.4.0]decane, 2,8-dimethyl

Bicycloelemene

Methyl acetate

Neomenthyl acetate

1-Decanol

Piperitone

Pulegone

$\alpha$-Terpineol

Menthol

Neoisomenthol

Menthone

$\gamma$-Terpinene

Eucalyptol

Myrcene

$\beta$-Pinene $=$

Sabinene ,

3-Methylcyclohexanone I

$\alpha$-Pinene
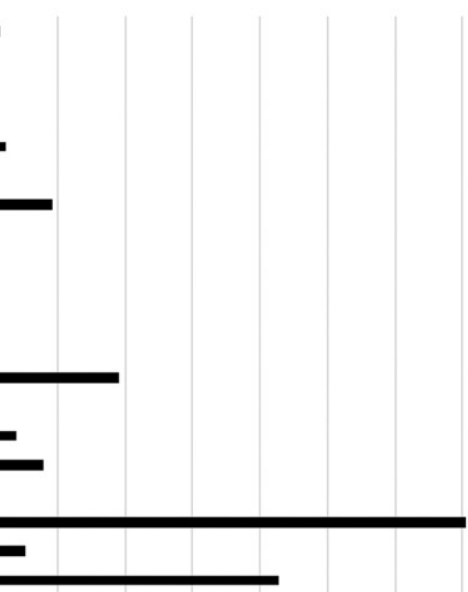

-

0

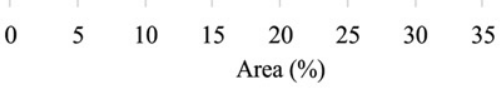

\section{Copaifera duckei}

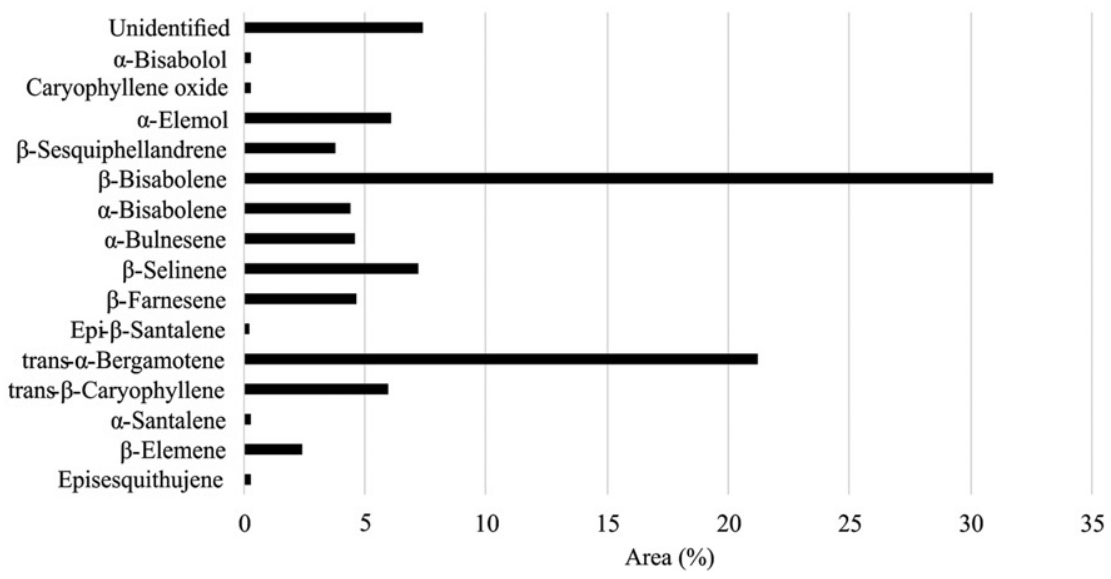

Fig. 1. Chemical composition of essential oils of Melaleuca alternifolia and Mentha piperita and Copaifera duckei oleoresin. 

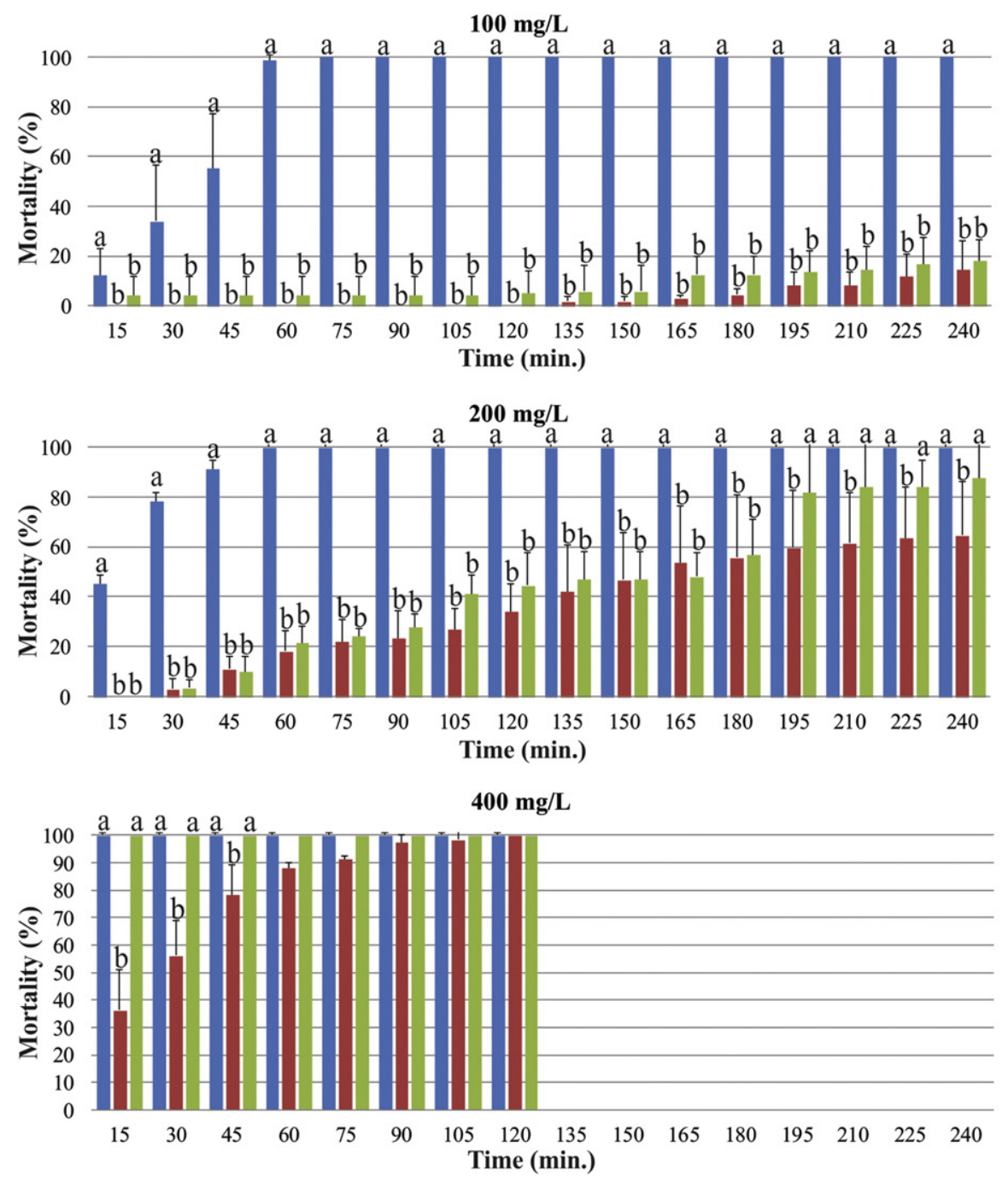

$800 \mathrm{mg} / \mathrm{L}$

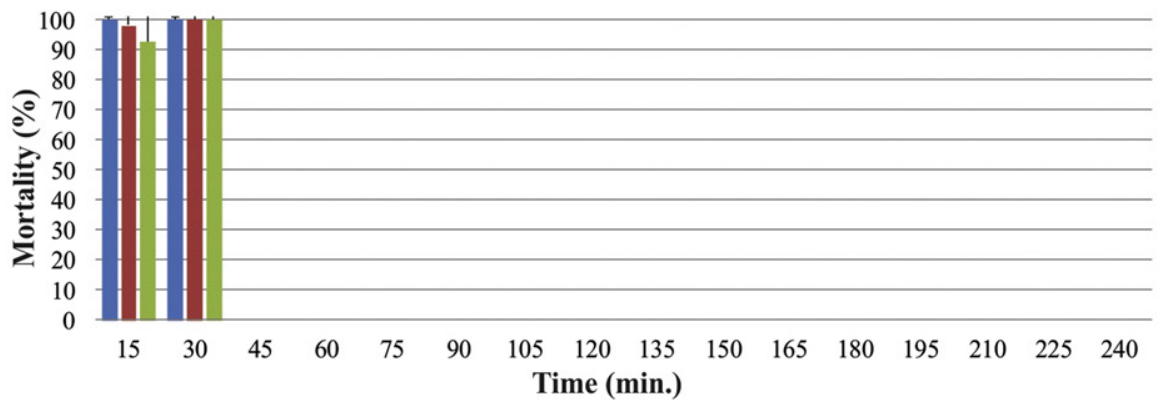

$1600 \mathrm{mg} / \mathrm{L}$

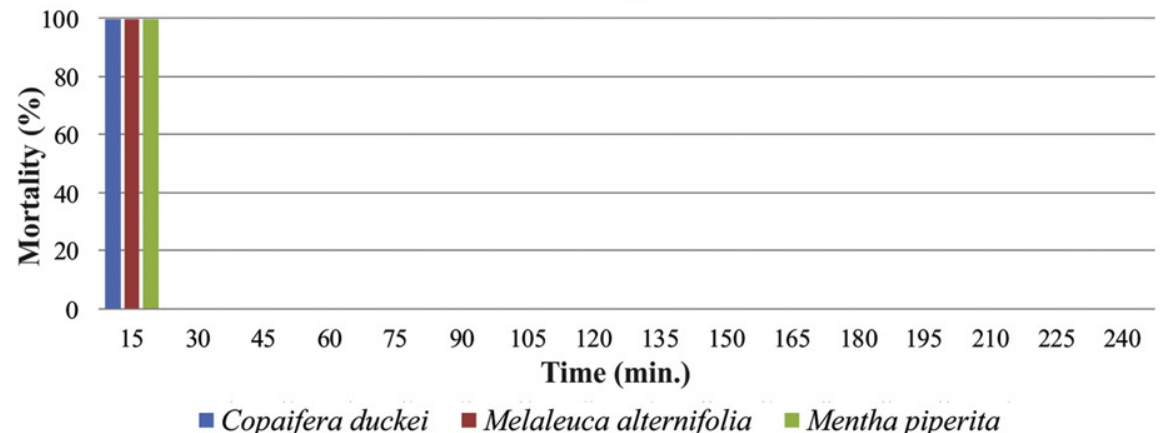

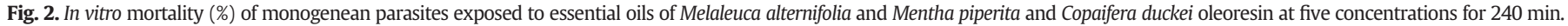


Table 1

Prevalence (\%) and mean intensity ( \pm standard deviation) of monogenean parasites in Piaractus mesopotamicus bathed with Copaifera duckei oleoresin.

\begin{tabular}{|c|c|c|c|c|c|c|}
\hline & Parasitism & Control & DMSO & C. duckei $10 \mathrm{mg} / \mathrm{L}$ & C. duckei $50 \mathrm{mg} / \mathrm{L}$ & $p$-Value \\
\hline \multirow{2}{*}{$0 \mathrm{~h}$ post-bath } & Prevalence (\%) & 100 & 100 & 100 & 100 & - \\
\hline & Mean intensity & $121.17 \pm 55.52 \mathrm{a}$ & $94.33 \pm 40.29 \mathrm{ab}$ & $83.17 \pm 35.38 b c$ & $54.33 \pm 32.25 c$ & $<0.001$ \\
\hline \multirow[t]{2}{*}{7 day post-bath } & Prevalence (\%) & 100 & 100 & 100 & 100 & - \\
\hline & Mean intensity & $21.64 \pm 18.17^{*}$ & $31.0 \pm 20.58^{*}$ & $32.67 \pm 21.9^{*}$ & $30.5 \pm 27.1^{*}$ & 0.347 \\
\hline
\end{tabular}

Means followed by different letters in the same row indicate significant differences by the Tukey's test $(p<0.05)$.

* Indicates significant differences between times.

Alanine aminotransferase (ALT) and aspartate aminotransferase (AST) levels (IU/L) were measured by ultraviolet-visible (UV-Vis) spectrophotometry with $50 \mu \mathrm{L}$ of serum using Labtest ${ }^{\circledR}$ kits \#108 and \#109, respectively, according to the manufacturer's recommendations. Blood glucose $\left(\mathrm{mg} \mathrm{dL}^{-1}\right)$ was measured using an Injex Sens II® glucose meter (Injex, Ourinhos, SP, Brazil).

\subsection{Histological analysis}

Immediately after the bath, the liver, spleen, kidney, and gills were collected and fixed in 10\% buffered formalin. After $24 \mathrm{~h}$, the tissues were transferred to $70 \%$ alcohol and processed for paraffin embedding. Histological sections (5-6 $\mu \mathrm{m}$ ) were stained with hematoxylin-eosin (H\&E) and gills were stained with periodic acid-Schiff. The alterations were analyzed with a Nikon Eclipse E200® optical microscope (Nikon, Tokyo, Japan) and images were captured with a Moticam 2300® camera (Motic, Hong Kong).

\subsection{Statistical analysis}

Data are expressed as mean \pm standard deviation. The parasite mortality from each phytotherapeutic agent tested in the in vitro and in vivo studies was compared using one-way analysis of variance (ANOVA) and treatment means were compared using the Tukey's test (LSMEANS command). $p$ values less than or equal to 0.05 were considered statistically significant. All analyses were performed using Statistical Analysis System (SAS Institute 2008).

\section{Results}

\subsection{Essential oil and chromatographic profile}

In total, 15, 27, and 15 volatile components were identified in $M$. alternifolia, M. piperita, and C. duckei, respectively (Fig. 1).

Terpinen-4-ol (39.8\%) and $\gamma$-terpinene (14.6\%) were the main constituents of M. alternifolia EO, whereas menthol (35.2\%), menthone

Table 2

Hematological parameters (mean \pm standard deviation) of Piaractus mesopotamicus bathed with Copaifera duckei oleoresin.

\begin{tabular}{|c|c|c|c|c|c|c|}
\hline & Parameter & Control & DMSO & C. duckei $10 \mathrm{mg} / \mathrm{L}$ & C. duckei $50 \mathrm{mg} / \mathrm{L}$ & $p$-Value \\
\hline \multirow{17}{*}{$0 \mathrm{~h}$ post-bath } & Hematocrit (\%) & $31.83 \pm 3.81$ & $32.66 \pm 4.69$ & $32.36 \pm 3.55$ & $31.91 \pm 3.26$ & 0.947 \\
\hline & Hemoglobin $\left(\mathrm{g} \mathrm{dL}^{-1}\right)$ & $7.29 \pm 0.72$ & $7.57 \pm 0.79$ & $7.02 \pm 0.83$ & $7.36 \pm 0.8$ & 0.475 \\
\hline & Erythrocytes $\left(\times 10^{6} \mu \mathrm{L}^{-1}\right)$ & $2.14 \pm 0.46$ & $2.28 \pm 0.46$ & $1.96 \pm 0.34$ & $2.01 \pm 0.29$ & 0.159 \\
\hline & $\operatorname{MCV}(\mathrm{fL})$ & $155.94 \pm 42.45$ & $147.35 \pm 33.95$ & $171.90 \pm 34.49$ & $160.86 \pm 21.41$ & 0.382 \\
\hline & $\mathrm{MCH}(\mathrm{pg})$ & $35.69 \pm 8.31$ & $34.19 \pm 6.17$ & $37.98 \pm 8.08$ & $38.67 \pm 5.96$ & 0.407 \\
\hline & $\operatorname{MCHC}\left(\mathrm{g} \mathrm{dL}^{-1}\right)$ & $23.38 \pm 3.38$ & $23.85 \pm 4.33$ & $22.36 \pm 3.28$ & $24.09 \pm 2.51$ & 0.646 \\
\hline & Glucose $\left(\mathrm{mg} \mathrm{dL}^{-1}\right)$ & $182.41 \pm 53.23$ & $198.5 \pm 51.37$ & $193.33 \pm 58.58$ & $234.00 \pm 53.35$ & 0.123 \\
\hline & Leukocytes $\left(\times 10^{3} \mu \mathrm{L}^{-1}\right)$ & $34.3 \pm 19.1$ & $32.67 \pm 17.46$ & $38.09 \pm 2.71$ & $30.27 \pm 16.02$ & 0.827 \\
\hline & Thrombocytes $\left(\times 10^{3} \mu \mathrm{L}^{-1}\right)$ & $49.63 \pm 35.55$ & $45.43 \pm 21.45$ & $34.83 \pm 17.79$ & $33.61 \pm 17.11$ & 0.293 \\
\hline & Monocytes $\left(\times 10^{3} \mu \mathrm{L}^{-1}\right)$ & $3.81 \pm 3.48$ & $4.11 \pm 3.85$ & $3.98 \pm 4.42$ & $3.44 \pm 2.33$ & 0.996 \\
\hline & Lymphocytes $\left(\times 10^{3} \mu \mathrm{L}^{-1}\right)$ & $26.03 \pm 17.34$ & $30.55 \pm 21.74$ & $28.73 \pm 25.43$ & $24.84 \pm 14.22$ & 0.825 \\
\hline & Neutrophils $\left(\times 10^{3} \mu \mathrm{L}^{-1}\right)$ & $2.09 \pm 2.26$ & $2.19 \pm 3.13$ & $1.99 \pm 1.73$ & $1.74 \pm 1.34$ & 0.882 \\
\hline & PAS-GL $\left(\times 10^{3} \mu \mathrm{L}^{-1}\right)$ & $0.09 \pm 0.17$ & $0.12 \pm 0.12$ & $0.39 \pm 0.67$ & $0.26 \pm 0.31$ & 0.761 \\
\hline & Total protein $\left(\mathrm{g} \mathrm{dL}^{-1}\right)$ & $2.79 \pm 0.33$ & $2.84 \pm 0.39$ & $2.84 \pm 0.42$ & $2.80 \pm 0.42$ & 0.987 \\
\hline & Albumin $\left(\mathrm{g} \mathrm{dL}^{-1}\right)$ & $0.62 \pm 0.18$ & $0.64 \pm 0.15$ & $0.63 \pm 0.13$ & $0.66 \pm 0.15$ & 0.92 \\
\hline & $\operatorname{ALT}(\mathrm{U} / \mathrm{L})$ & $5.46 \pm 1.81$ & $6.15 \pm 2.06$ & $6.77 \pm 1.89$ & $6.57 \pm 2.21$ & 0.425 \\
\hline & AST $(\mathrm{U} / \mathrm{L})$ & $41.05 \pm 16.6$ & $44.58 \pm 16.71$ & $44.57 \pm 15.39$ & $45.95 \pm 12.6$ & 0.894 \\
\hline \multirow[t]{17}{*}{7 day post-bath } & Hematocrit (\%) & $31.58 \pm 2.81$ & $32.50 \pm 2.06$ & $32.16 \pm 2.03$ & $32.91 \pm 2.93$ & 0.612 \\
\hline & Hemoglobin $\left(\mathrm{g} \mathrm{dL}^{-1}\right)$ & $7.7 \pm 0.96$ & $8.24 \pm 0.74$ & $7.97 \pm 0.6$ & $7.89 \pm 0.61$ & 0.375 \\
\hline & Erythrocytes $\left(\times 10^{6} \mu \mathrm{L}^{-1}\right)$ & $1.35 \pm 0.24^{*}$ & $1.45 \pm 0.24^{*}$ & $1.44 \pm 0.3^{*}$ & $1.41 \pm 0.26^{*}$ & 0.758 \\
\hline & $\operatorname{MCV}(\mathrm{fL})$ & $241.52 \pm 49.21^{*}$ & $229.38 \pm 40.14^{*}$ & $233.03 \pm 58.5^{*}$ & $241.72 \pm 53.28^{*}$ & 0.913 \\
\hline & $\mathrm{MCH}(\mathrm{pg})$ & $58.73 \pm 11.88^{*}$ & $58.03 \pm 10.42^{*}$ & $57.18 \pm 11.01^{*}$ & $57.34 \pm 9.63^{*}$ & 0.984 \\
\hline & $\mathrm{MCHC}\left(\mathrm{g} \mathrm{dL}^{-1}\right)$ & $24.4 \pm 2.3$ & $25.47 \pm 3.05$ & $24.88 \pm 2.49$ & $24.16 \pm 2.91$ & 0.652 \\
\hline & Glucose $\left(\mathrm{mg} \mathrm{dL}^{-1}\right)$ & $120.66 \pm 38.07^{*}$ & $105.83 \pm 18.9^{*}$ & $108.5 \pm 23.33^{*}$ & $109.66 \pm 25.48^{*}$ & 0.567 \\
\hline & Leukocytes $\left(\times 10^{3} \mu \mathrm{L}^{-1}\right)$ & $18.65 \pm 15.35$ & $23.86 \pm 7.88$ & $16.84 \pm 8.38$ & $22.34 \pm 11.96$ & 0.409 \\
\hline & Thrombocytes $\left(\times 10^{3} \mu \mathrm{L}^{-1}\right)$ & $22.09 \pm 15.28$ & $30.54 \pm 13.16$ & $27.02 \pm 20.99$ & $24.89 \pm 11.60$ & 0.606 \\
\hline & Monocytes $\left(\times 10^{3} \mu \mathrm{L}^{-1}\right)$ & $0.48 \pm 0.29^{*}$ & $1.06 \pm 1.02^{*}$ & $0.81 \pm 0.65^{*}$ & $0.74 \pm 0.61$ & 0.08 \\
\hline & Lymphocytes $\left(\times 10^{3} \mu \mathrm{L}^{-1}\right)$ & $17.81 \pm 15.49$ & $22.23 \pm 7.87$ & $15.10 \pm 8.53$ & $20.58 \pm 10.85$ & 0.155 \\
\hline & Neutrophils $\left(\times 10^{3} \mu \mathrm{L}^{-1}\right)$ & $0.29 \pm 0.22^{*}$ & $0.43 \pm 0.55$ & $0.79 \pm 1.26$ & $0.34 \pm 0.4$ & 0.555 \\
\hline & PAS-GL $\left(\times 10^{3} \mu \mathrm{L}^{-1}\right)$ & $0.08 \pm 0.06$ & $0.14 \pm 0.21$ & $0.15 \pm 0.18$ & $0.24 \pm 0.32$ & 0.135 \\
\hline & Total protein $\left(\mathrm{g} \mathrm{dL}^{-1}\right)$ & $3.80 \pm 0.31^{*}$ & $3.91 \pm 0.42^{*}$ & $3.94 \pm 0.48^{*}$ & $3.85 \pm 0.43^{*}$ & 0.861 \\
\hline & Albumin $\left(\mathrm{g} \mathrm{dL}^{-1}\right)$ & $0.84 \pm 0.36$ & $1.09 \pm 0.34^{*}$ & $0.80 \pm 0.32$ & $1.13 \pm 0.45^{*}$ & 0.084 \\
\hline & $\operatorname{ALT}(\mathrm{U} / \mathrm{L})$ & $3.63 \pm 1.17^{*}$ & $3.56 \pm 1.35^{*}$ & $3.60 \pm 2.05^{*}$ & $3.31 \pm 1.05^{*}$ & 0.949 \\
\hline & AST (U/L) & $42.36 \pm 16.33$ & $48.19 \pm 20.6$ & $51.01 \pm 41.39$ & $50.59 \pm 38.62$ & 0.899 \\
\hline
\end{tabular}

* Indicates significant differences between times. 
(21.4\%), and eucalyptol (10.1\%) were the main components of $M$. piperita EO.

The volatile fraction of $C$. duckei OR was mainly composed of $\beta$ bisabolene (30.9\%) and trans- $\alpha$-bergamotene (21.9\%). Analysis by HPLC-MS/MS of the OR also revealed the following metabolites: entagathic-15-methyl ester, ent-agathic acid, and ent-polyalthic acid.

\subsection{In vitro assay}

The EOs of M. alternifolia and M. piperita resulted in 100\% parasite mortality at $400 \mathrm{mg} / \mathrm{L}$, whereas C. duckei OR eliminated $100 \%$ of parasites even at the lowest concentration $(100 \mathrm{mg} / \mathrm{L})$. During this trial, we observed swelling and lysis of the parasites that were killed by the action of the phytotherapeutic agents.

No parasite mortality was observed in control groups (non-exposed fish and fish exposed to DMSO) during the $4 \mathrm{~h}$ of evaluation, indicating that parasites were not affected by baths with DMSO and water only.

At the lower concentration (100 mg/L) and in the first hour, C. duckei OR showed the highest efficacy ( $p<0.05$ ), with $98.7 \%$ of monogenean mortality versus 0 and $4.2 \%$ for $M$. alternifolia and $M$. piperita, respectively. At this concentration, after $4 \mathrm{~h}$ of evaluation, $C$. duckei OR continued to be more effective $(p<0.05)$ than the other essential oils (Fig. 2). At $200 \mathrm{mg} / \mathrm{L}, C$. duckei OR showed greater efficacy $(p<0.05)$ than $M$. alternifolia and M. piperita EOs until $3 \mathrm{~h}$ of evaluation (Fig. 2). In addition, at $400 \mathrm{mg} / \mathrm{L}$, M. alternifolia EO was less effective $(p<0.05)$ than $C$. duckei $\mathrm{OR}$ and M. piperita EO. Lastly, no significant differences in efficacy were observed over the trial period between the three phytotherapeutic agents at the highest concentrations (800 and $1600 \mathrm{mg} / \mathrm{L}$ ) (Fig. 2).

\subsection{In vivo assays}

Before reporting on the parasitological, biochemical and histological analyses performed on the studied fish, it is important to note that neither treated fish nor non-treated fish showed any behavioral changes, anorexia, hypoxia, or any other changes as a result of treatments using C. duckei OR

\subsubsection{Parasitological analysis}

Parasite numbers were significantly reduced $(p<0.05)$ after just one 10-min bath with $C$. duckei OR. Short baths with OR at $50 \mathrm{mg} / \mathrm{L}$ were more effective $(p<0.05)$ than the other groups, with approximately $45 \%$ reduction in the mean intensity of parasitism (Table 1 ). However, no significant difference in mean intensity of parasitism was observed across treatments seven days post-treatment (Table 1 ).

\subsubsection{Effect of C. duckei OR on the host}

Blood parameters of fish bathed with C. duckei OR at 10 and $50 \mathrm{mg} / \mathrm{L}$ and DMSO were not significantly altered compared to those of control fish ( $p>0.05$, Table 2$)$. However, neutrophil counts were significantly reduced in the control group $(p<0.05)$ seven days post-treatment. $\mathrm{MCV}, \mathrm{MCH}$, total protein, and albumin levels were significantly higher $(p<0.05)$ seven days post-bath, whereas blood glucose and monocyte counts were significantly reduced $(p<0.05)$ in all groups (Table 2 ).

\subsection{Histological analysis}

Histological analysis revealed branchial and hepatic changes in fish from all groups, including the control group. Analysis of the gill tissue showed hyperplasia and hypertrophy, resulting in moderate fusion of secondary lamellae (Fig. 3). Hepatocytes showed moderate to extensive swelling and the loss of tissue organization in some areas is suggestive of focal necrosis (Fig. 3). No changes were observed in splenic and kidney tissues.

\section{Discussion}

Despite the histopathological changes observed in fish from all groups, none were caused by the therapeutic baths. The phytotherapeutic
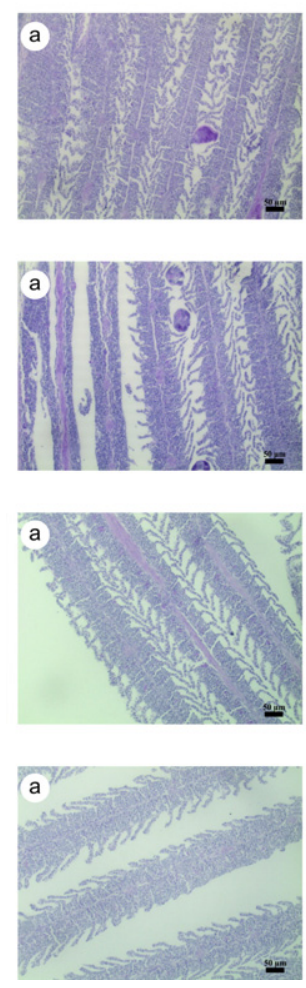

Control
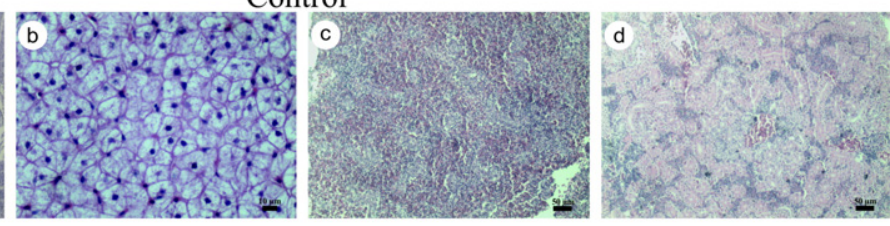

DMSO
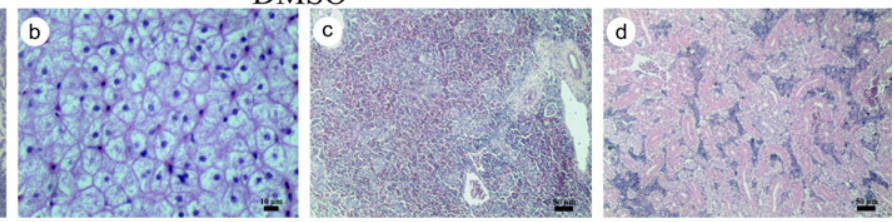

C. duckei $10 \mathrm{mg} / \mathrm{L}$
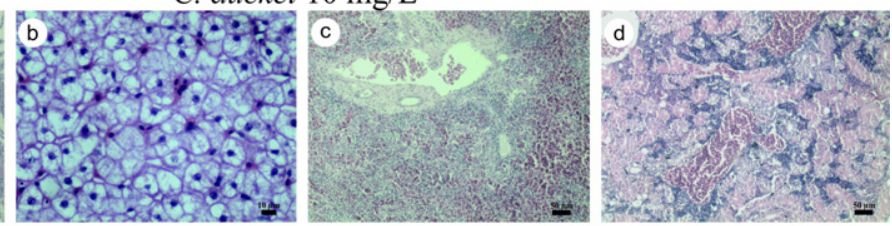

C. duckei $50 \mathrm{mg} / \mathrm{L}$
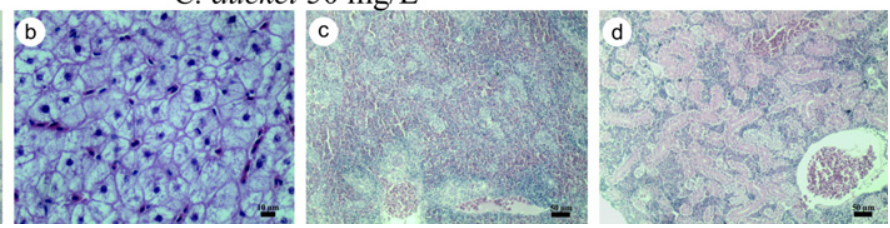

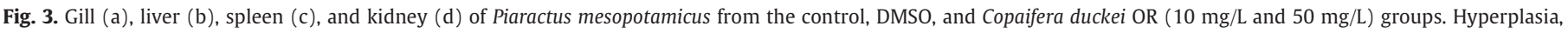

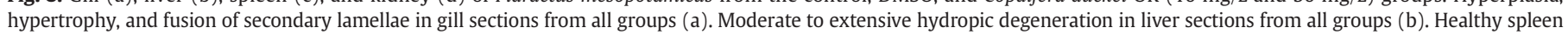
and kidneys ( $\mathrm{c}$ and $\mathrm{d}$ ). 
agents evaluated here, especially $C$. duckei $\mathrm{OR}$, showed great potential for controlling monogenean parasites.

Previous studies have shown the efficacy of $M$. alternifolia (Steverding et al., 2005) and M. piperita (Hashimoto et al., 2016; Malheiros et al., 2016) against monogenean parasites, but this is the first time that the effect of $C$. duckei OR has been evaluated against these fish pathogens. Results of the in vitro study revealed that $C$. duckei was more effective than $M$. alternifolia and M. piperita. Specifically, $C$. duckei OR caused swelling and lysis of monogenean parasites, suggesting that its mode of action is similar to that of other plant extracts that have been tested against protozoan parasites (Zhang et al., 2013; Valladão et al., 2016a), in which the permeabilization of the membrane lead to swelling and lysis of the parasite. The main constituents of $C$. duckei OR identified in the current study were $\beta$-bisabolene and trans$\alpha$-bergamotene.

In the in vivo study, baths with $C$. duckei OR at $50 \mathrm{mg} / \mathrm{L}$ for $10 \mathrm{~min}$ were effective in killing monogenean parasites, reducing by $45 \%$ the intensity of parasitism. Seven days after the baths, fish from all groups had lower parasite infestation rates, which was probably due to the handling of fish (moving fish from tanks to buckets for treatment) and reduction of stocking density. The in vivo treatment strategies used in previous studies included short or long as well as single or repeated baths, making comparisons across studies difficult (Valladão et al., 2015). Indeed, different types of herbal medicines, EOs, extracts, and isolated compounds have been tested before against fish monogeneans. Levy et al. (2015) showed in Poecilia reticulata (Peters, 1859) that short 30-min baths with ethanol extract of Zingiber officinale significantly reduced parasitism by Gyrodactylus turnbulli. Boijink et al. (2016) showed in Colossoma macropomum (Cuvier, 1818) that short 15-min baths with Ocimum gratissimum EO were effective in killing $100 \%$ of monogenean parasites. In long bath ( $2 \mathrm{~h}$ or $12 \mathrm{~h}$ ) using Bixa orellana seed extract at 125 and $250 \mathrm{mg} / \mathrm{L}$, Andrade et al. (2016) obtained 100\% of efficacy against monogenean of $C$. macropomum. However, nothing is known about the use of OR in aquaculture. The results of this study will enable the development of novel treatment strategies using C. duckei OR against other major fish pathogens and in other hosts. In addition, innovations in the solubilization of OR in water can further enhance the action of this herbal medicine. For instance, Rodrigues et al. (2014) reported that $C$. duckei OR showed the best solubilization using nanoemulsion, which is essential for the stability of its constituents.

Therapeutic baths with $C$. duckei OR did not alter the hematological parameters of fish either immediately after treatment or seven days post-treatment, indicating that treatment with this OR is safe for pacu. The unaltered $\mathrm{MCV}, \mathrm{MCH}$, total protein, and albumin levels, the increased glucose values, and lower monocyte counts in all groups at day 7 probably occurred because of the handling of fish and not due to treatments. Other studies have described hematological changes in fish treated with different herbal medicines. For instance, Hashimoto et al. (2016) reported a reduction in RBC and thrombocyte counts and an increase in hematocrit, neutrophil, and glucose levels in Nile tilapia Oreochromis niloticus (Linnaeus, 1758) given three baths with $40 \mathrm{mg} / \mathrm{L}$ of Lippia sidoides EO for 10 min with a 24-h interval between baths. Further, C. macropomum bathed for $30 \mathrm{~min}$ with $150 \mathrm{mg} / \mathrm{L}$ of Lippia alba EO showed reduced RBC and hematocrit values and increased glucose, MCHC, and thrombocyte levels due to stress (Soares et al., 2016).

Histopathology analysis revealed that fish from all groups had gill alterations, which were related to the intensity of parasitism. In fact, baths with $50 \mathrm{mg} / \mathrm{L}$ of $C$. duckei OR reduced parasite loads by approximately $45 \%$ without causing extra damage to the gill tissue. This is particularly interesting given the lack of studies phytotherapeutic potential harmful effects on host health and their association with dose and exposure time, as highlighted by (Valladão et al., 2015). Recently, Malheiros et al. (2016) showed that baths with $160 \mathrm{mg} / \mathrm{L}$ of M. piperita EO for $4 \mathrm{~h}$ caused epithelial displacement, fusion of secondary lamellae, hypertrophy, aneurysm, and necrosis in the gills of Arapaima gigas. Soares et al. (2016) reported that 30-min baths with 100 and $150 \mathrm{mg} / \mathrm{L}$ of L. alba
EO caused hyperplasia, fusion of the lamellar epithelium, capillary dilatation, displacement of the lamellar epithelium, aneurysm, epithelial disruption with hemorrhage, congestion, and necrosis in C. macropomum gills. The liver alterations were observed in both untreated and treated fish, it may be related to fish cultivation or diet conditions, but were not worsened by treatment with $C$. duckei OR. Indeed, this phytotherapeutic agent did not cause any detectable changes to spleen and kidney tissues, suggesting that its use is safe under the tested conditions.

Copaifera duckei OR showed strong anthelmintic activity in in vitro and in vivo tests against monogenean parasites of pacu, which are among the major parasitic platyhelminths in aquaculture worldwide. Under the conditions tested, this herbal medicine was safe for use in pacu due to its rapid action even in low concentrations, which reduces costs and facilitates the implementation of the treatment protocol. Nevertheless, further testing with different doses and exposure times is warranted to improve the treatment including testing other doses and times that could be even more effective. The use of $C$. duckei OR offers an environmentally friendly alternative for treating parasitic infections in aquaculture by directly and/or indirectly reducing the use of chemotherapy and antibiotics.

\section{Conflict of interest}

The authors declare no conflicts of interest.

\section{Acknowledgements}

The authors thank CAPES (Coordenação de Aperfeiçoamento de Pessoal de Nível Superior) for scholarship to J.C. Costa; and São Paulo Research Foundation (FAPESP) for financial support, which enabled the extraction and characterization of copaiba oil used in this study (project number 2011/13630-7).

\section{References}

Andrade, J.I.A., Jeronimo, G.T., Brasil, E.M., Nunez, C.V., Gonçalves, E.L.T., Ruiz, M.L., Martins, M.L., 2016. Efficacy of seed extract of Bixa orellana against monogenean gill parasites and physiological aspects of Colossoma macropomum after bath treatment. Aquaculture 462:40-46. http://dx.doi.org/10.1016/j.aquaculture.2016.04.024.

Araújo, C.S.O., Tavares-Dias, M., Gomes, A.L.S., Andrade, S.M.S., Lemos, J.R.G., Oliveira, A.D. Affonso, E.G., 2009. Infecções parasitárias e parâmetros sanguíneos em Arapaima gigas Schinz, 1822 (Arapaimidae) cultivados no estado do Amazonas, Brasil. Manejo e sanidade de peixes em Cultivo 1. Embrapa Amapá, Macapá, pp. 389-424.

Baldin, E.L.L., Crotti, A.E.M., Wakabayashi, K.A.L., Silva, J.P.G.F., Aguiar, G.P., Souza, E.S., Veneziani, R.C.S., Groppo, M., 2013. Plant-derived essential oils affecting settlement and oviposition of Bemisia tabaci (Genn.) biotype B on tomato. J. Pest. Sci. 86: 301-308. http://dx.doi.org/10.1007/s10340-012-0462-x.

Bardají, D.K.R., da Silva, J.J.M., Bianchi, T.C., de Souza Eugênio, D., de Oliveira, P.F., Leandro L.F., Rogez, H.L.G., Venezianni, R.C.S., Ambrosio, S.R., Tavares, D.C., Bastos, J.K., Martins, C.H.G., 2016. Copaifera reticulata oleoresin: chemical characterization and antibacterial properties against oral pathogens. Anaerobe 40:18-27. http://dx.doi.org/10.1016/j. anaerobe.2016.04.017.

Benavides-González, F., Gomez-Flores, R.A., Rábago-Castro, J.L., Sánchez-Martínez, J.G. Montelongo-Alfaro, I.O., 2015. Effects of hydrogen peroxide and metrifonate on monogenean Ligictaluridus floridanus on catfish (Ictalurus punctatus, Rafinesque) gills. J. Parasitol. 101:707-710. http://dx.doi.org/10.1645/15-791.

Boeger, W.A., Husak, W.S., Martins, M.L., 1995. Neotropical monogenoidea. 25 Anacanthorus penilabiatus n. sp. (Dactylogyridae, Anacanthorinae) from Piaractus mesopotamicus (Osteichthyes, Serrasalmidae), cultivated in the state of São Paulo, Brazil. Mem. Inst. Oswaldo Cruz 90, 699-701.

Boeger, W.A., Piasecki, W., Sobecka, E., 2002. Neotropical Monogenoidea. 44 Mymarothecium viatorum sp. n. [Ancyrocephalinae] from the gills of Piaractus brachypomus [Serrasalmidae, Teleostei] captured in a warm-water canal of a power plant in Szczecin, Poland. Acta Ichthyol. Piscat. 32.

Boijink, C.L., Queiroz, C.A., Chagas, E.C., Chaves, F.C.M., Inoue, L.A.K.A., 2016. Anesthetic and anthelminthic effects of clove basil (Ocimum gratissimum) essential oil for tambaqui (Colossoma macropomum). Aquaculture 457:24-28. http://dx.doi.org/10. 1016/j.aquaculture.2016.02.010.

Bowker, J.D., Carty, D., Dotson, M.M., 2012. Efficacy of 35\% PEROX-AID (hydrogen peroxide) in reducing an infestation of Gyrodactylus salmonis in freshwater-reared rainbow trout. N. Am. J. Aquac. 74:154-159. http://dx.doi.org/10.1080/15222055.2012. 675992.

Bush, A.O., Lafferty, K.D., Lotz, J.M., Shostak, A.W., 1997. Parasitology meets ecology on its own terms: Margolis et al. revisited. J. Parasitol. 575-583. 
Dorneles, F.d.S., Silva, A.S.d., Oliveira, C.B., Zimmermann, C.E.P., Rosa, L.D., Tonin, A.A., Oliveira, E.C.P.d., Santurio, J.M., Monteiro, S.G., 2013. Susceptibility of Trypanosoma evansi in the copaiba oil: in vitro test and in mice experimentally infected with the parasite. Acta Sci. Vet. 41, 1136.

Fajer-Ávila, E.J., La, P., De, I.A., Aguilar-Zarate, G., Contreras-Arce, R., Zaldívar-Ramírez, J. Betancourt-Lozano, M., 2003. Toxicity of formalin to bullseye puffer fish (Sphoeroides annulatus Jenyns, 1843) and its effectiveness to control ectoparasites. Aquaculture 223:41-50. http://dx.doi.org/10.1016/S0044-8486(03)00166-2.

Forwood, J.M., Harris, J.O., Deveney, M.R., 2013. Efficacy of current and alternative bath treatments for Lepidotrema bidyana infecting silver perch, Bidyanus bidyanus. Aquaculture 416-417:65-71. http://dx.doi.org/10.1016/j.aquaculture.2013.08.034.

Gilbert, B.M., Baker, W.B., Tomassini, P.M., Goulart, T.C.B., Holanda, E.G., Costa, J.C., Lopes, J.A.R., Santos, J.N.G., Sarti, F.D., Turco, S.J., Vichenewski, A.M., Lopes, W., Thanes, J.L.C. Pellegrino, A.W., Katz, J.N., 1972. A atividade anti-helmíntica de óleos essenciais e de seus componentes químicos. An. Acad. Bras. Cienc. 44, 423-428.

Hashimoto, G.S.O., Neto, F.M., Ruiz, M.L., Acchile, M., Chagas, E.C., Chaves, F.C.M., Martins, M.L., 2016. Essential oils of Lippia sidoides and Mentha piperita against monogenean parasites and their influence on the hematology of Nile tilapia. Aquaculture 450: 182-186. http://dx.doi.org/10.1016/j.aquaculture.2015.07.029.

Hesser, E.F., 1960. Methods for routine fish hematology. Progress. Fish Cult. 22, 164-171.

Hirazawa, N., Tsubone, S., Takano, R., 2016. Anthelmintic effects of 75 ppm hydrogen peroxide treatment on the monogeneans Benedenia seriolae, Neobenedenia girellae, and Zeuxapta japonica infecting the skin and gills of greater amberjack Seriola dumerili. Aquaculture 450:244-249. http://dx.doi.org/10.1016/j.aquaculture.2015.07.028.

Huang, A.G., Yi, Y.L., Ling, F., Lu, L., Zhang, Q.Z., Wang, G.X., 2013. Screening of plant extracts for anthelmintic activity against Dactylogyrus intermedius (Monogenea) in goldfish (Carassius auratus). Parasitol. Res. 112:4065-4072. http://dx.doi.org/10. 1007/s00436-013-3597-7.

Izumi, E., Ueda-Nakamura, T., Veiga-Júnior, V.F., Nakamura, C.V., 2013. Toxicity of oleoresins from the genus Copaifera in Trypanosoma cruzi: a comparative study. Planta Med. 79, 952-958

Levy, G., Zilberg, D., Paladini, G., Fridman, S., 2015. Efficacy of ginger-based treatments against infection with Gyrodactylus turnbulli in the guppy (Poecilia reticulata (Peters)). Vet. Parasitol. 209:235-241. http://dx.doi.org/10.1016/j.vetpar.2015.03.002.

Malheiros, D.F., Maciel, P.O., Videira, M.N., Tavares-Dias, M., 2016. Toxicity of the essentia oil of Mentha piperita in Arapaima gigas (pirarucu) and antiparasitic effects on Dawestrema spp. (Monogenea). Aquaculture 455:81-86. http://dx.doi.org/10.1016/j. aquaculture.2016.01.018.

McKay, D.L., Blumberg, J.B., 2006. A review of the bioactivity and potential health benefits of peppermint tea (Mentha piperita L.). Phytother. Res. http://dx.doi.org/10.1002/ptr. 1936.

Ogawa, K., 2014. Diseases of cultured marine fishes caused by Platyhelminthes (Monogenea, Digenea, Cestoda). Parasitology 142:178-195. http://dx.doi.org/10. 1017/S0031182014000808.

Pahor-Filho, E., Miranda-Filho, K.C., Pereira Júnior, J., 2012. Parasitology of juvenile mullet (Mugil liza) and effect of formaldehyde on parasites and host. Aquaculture 354-355: 111-116. http://dx.doi.org/10.1016/j.aquaculture.2012.03.032.

Paiva, L.A.F., Gurgel, L.A., Campos, A.R., Silveira, E.R., Rao, V.S.N., 2004. Attenuation of ischemia/reperfusion-induced intestinal injury by oleo-resin from Copaifera langsdorffii in rats. Life Sci. 75:1979-1987. http://dx.doi.org/10.1016/j.lfs.2004.05.011.

Ranzani-Paiva, M.J.T., Pádua, S.B., Tavares-Dias, M., Egami, M.I., 2013. Métodos para análise hematologia de peixes. 1a ed. Editora da Universidade Estadual de Maringá, Maringá, p. 142.

Reverter, M., Bontemps, N., Lecchini, D., Banaigs, B., Sasal, P., 2014. Use of plant extracts in fish aquaculture as an alternative to chemotherapy: current status and future perspectives. Aquaculture 433:50-61. http://dx.doi.org/10.1016/j.aquaculture.2014.05 048.

Rico, A., Van den Brink, P.J., 2014. Probabilistic risk assessment of veterinary medicines applied to four major aquaculture species produced in Asia. Sci. Total Environ. 468: 630-641. http://dx.doi.org/10.1016/j.scitotenv.2013.08.063.
Rodrigues, E.d.C.R., Ferreir, A.M., Vilhen, J.C.E., Almeida, F.B., Cruz, R.A.S., Florentino, A.C., Souto, R.N.P., Carvalho, J.C.T., Fernandes, C.P., 2014. Development of a larvicidal nanoemulsion with copaiba (Copaifera duckei) oleoresin. Brazilian J. Pharmacogn. 24:699-705. http://dx.doi.org/10.1016/j.bjp.2014.10.013.

Santiago, K.B., Conti, B.J., Andrade, B.F.M.T., Silva, J.J.M.d., Rogez, H.L.G., Crevelin, E.J., Beraldo de Moraes, L.A., Veneziani, R.C.S., Ambrósio, S.R., Bastos, J.K., Sforcin, J.M., 2015. Immunomodulatory action of Copaifera spp. oleoresins on cytokine production by human monocytes. Biomed. Pharmacother. 70:12-18. http://dx.doi.org/10.1016/j. biopha.2014.12.035.

Santos, A.O., Ueda-Nakamura, T., Dias Filho, B.P., Veiga Junior, V.F., Pinto, A.C., Nakamura, C.V., 2008. Effect of Brazilian copaiba oils on Leishmania amazonensis. J. Ethnopharmacol. 120:204-208. http://dx.doi.org/10.1016/j.jep.2008.08.007.

Sapkota, A., Sapkota, A.R., Kucharski, M., Burke, J., McKenzie, S., Walker, P., Lawrence, R., 2008. Aquaculture practices and potential human health risks: current knowledge and future priorities. Environ. Int. 34:1215-1226. http://dx.doi.org/10.1016/j.envint. 2008.04.009.

Sharp, N.J., Diggles, B.K., Poortenaar, C.W., Willis, T.J., 2004. Efficacy of Aqui-S, formalin and praziquantel against the monogeneans, Benedenia seriolae and Zeuxapta seriolae, infecting yellowtail kingfish Seriola lalandi lalandi in New Zealand. Aquaculture 236: 67-83. http://dx.doi.org/10.1016/j.aquaculture.2004.02.005.

Sitjà-Bobadilla, A., de Felipe, M.C., Alvarez-Pellitero, P., 2006. In vivo and in vitro treatments against Sparicotyle chrysophrii (Monogenea: Microcotylidae) parasitizing the gills of gilthead sea bream (Sparus aurata L.). Aquaculture 261:856-864. http://dx. doi.org/10.1016/j.aquaculture.2006.09.012.

Soares, B.V., Neves, L.R., Oliveira, M.S.B., Chaves, F.C.M., Dias, M.K.R., Chagas, E.C., TavaresDias, M., 2016. Antiparasitic activity of the essential oil of Lippia alba on ectoparasites of Colossoma macropomum (tambaqui) and its physiological and histopathological effects. Aquaculture 452:107-114. http://dx.doi.org/10.1016/j.aquaculture.2015.10. 029 .

Steverding, D., Morgan, E., Tkaczynski, P., Walder, F., Tinsley, R., 2005. Effect of Australian tea tree oil on Gyrodactylus spp. infection of the three-spined stickleback Gasterosteus aculeatus. Dis. Aquat. Org. 66:29-32. http://dx.doi.org/10.3354/dao066029.

Tavares-Dias, M., Moraes, F.R., Martins, M.L., 2008. Hematological assessment in four Brazilian teleost fish with parasitic infections, collected in feefishing from Franca, São Paulo, Brazil. Bol. do Inst. Pesca 34, 189-196.

Thatcher, V.E., 2006. Amazon Fish Parasites. second ed. Pensoft, Sofia, Moscow, p. 508.

Thomsen, P.S., Jensen, T.M., Hammer, K.A., Carson, C.F., Mølgaard, P., Riley, T.V., 2011. Survey of the antimicrobial activity of commercially available Australian tea tree (Melaleuca alternifolia) essential oil products in vitro. J. Altern. Complement. Med. 17: 835-841. http://dx.doi.org/10.1089/acm.2010.0508.

Umeda, N., Nibe, H., Hara, T., Hirazawa, N., 2006. Effects of various treatments on hatching of eggs and viability of oncomiracidia of the monogenean Pseudodactylogyrus anguillae and Pseudodactylogyrus bini. Aquaculture 253:148-153. http://dx.doi.org/ 10.1016/j.aquaculture.2005.08.009.

Valladão, G.M.R., Gallani, S.U., Pilarski, F., 2015. Phytotherapy as an alternative for treating fish disease. J. Vet. Pharmacol. Ther. 38:417-428. http://dx.doi.org/10.1111/jvp. 12202.

Valladão, G.M.R., Gallani, S.U., Ikefuti, C.V., da Cruz, C., Levy-Pereira, N., Rodrigues, M.V.N., Pilarski, F., 2016a. Essential oils to control ichthyophthiriasis in pacu, Piaractus mesopotamicus (Holmberg): special emphasis on treatment with Melaleuca alternifolia. J. Fish Dis. http://dx.doi.org/10.1111/jfd.12447 (n/a-n/a).

Valladão, G.M.R., Gallani, S.U., Pilarski, F., 2016b. South American fish for continental aquaculture. Rev. Aquac. 1-19. http://dx.doi.org/10.1111/raq.12164.

Veiga, V.F., Pinto, A.C., 2002. The Copaifera L. genus. Quim Nova 25, 273-286.

Zhang, Q., Xu, D.H., Klesius, P.H., 2013. Evaluation of an antiparasitic compound extracted from Galla chinensis against fish parasite Ichthyophthirius multifiliis. Vet. Parasitol. 198:45-53. http://dx.doi.org/10.1016/j.vetpar.2013.08.019. 